\title{
Medievalista
}

Online

23 | 2018

Número 23

\section{"El maestre Davis que se fazia llamar rede Portugal" - La imagen propagandística de D. João I de Portugal en la fuentes castellanas}

"The Davis' Master that called himself King of Portugal". The propagandistic image of D. João of Portugal in the Castillian sources

Néstor Vigil Montes

OpenEdition

Journals

Edición electrónica

URL: http://journals.openedition.org/medievalista/1629

DOI: $10.4000 /$ medievalista.1629

ISSN: 1646-740X

Editor

Instituto de Estudos Medievais - FCSH-UNL

Edición impresa

Fecha de publicación: 1 enero 2018

Referencia electrónica

Néstor Vigil Montes, "El maestre Davis que se fazia llamar rede Portugal" - La imagen

propagandística de D. João I de Portugal en la fuentes castellanas », Medievalista [En línea], 23 | 2018,

Puesto en línea el 07 mayo 2018, consultado el 20 abril 2019. URL : http://journals.openedition.org/ medievalista/1629; DOI : 10.4000/medievalista.1629

Este documento fue generado automáticamente el 20 abril 2019.

(c) IEM 


\section{"El maestre Davis que se fazia llamar rede Portugal" - La imagen propagandística de D. João I de Portugal en la fuentes castellanas}

"The Davis' Master that called himself King of Portugal". The propagandistic image of D. João of Portugal in the Castillian sources

Néstor Vigil Montes

\section{NOTA DEL EDITOR}

Data recepção do artigo: 16-03-2017

Data aceitação do artigo: 20-10-2017

"El maestre Davis que se fazia llamar rey de Portugal" - La imagen propagandística de D. João I en las fuentes castellanas / “The Davis' Master that called himself King of Portugal". The propagandistic image of D. João of Portugal in the

Castillian sources Néstor Vigil Montes

\section{Introducción}

No diremos nada nuevo si afirmamos que D. João I de Portugal es una de las figuras clave en la historia lusa. Tampoco si señalamos que la historiografía portuguesa tradicionalmente nos ha trasladado la imagen propagandística que el propio monarca y sus herederos se encargaron de construir para reforzar su nueva dinastía. Así, nos aparece constantemente el monarca "de boa memoria", que garantizó la independencia del 
Reino de Portugal y le otorgó la misión histórica de expandir al ultramar la fe cristiana ${ }^{1}$. En los esfuerzos de la historiografía portuguesa reciente por trasmitir una imagen más realista sobre el fundador de la dinastía Avis, creemos necesario reconstruir el discurso propagandístico opuesto, el creado por los monarcas castellanos como rivales en los derechos al trono portugués.

2 Este discurso propagandístico de los castellanos fue de sobra conocido por la historiografía portuguesa ${ }^{2}$ desde los inicios de la construcción de la propaganda dinástica. Fernão Lopes en su Crónica de D. João I utilizó las crónicas de Pedro López de Ayala como fuente principal, sin dudar en copiarlo literalmente en ocasiones, ni en omitir deliberadamente casi todos los extractos perjudiciales para su discurso ${ }^{3}$. El propio Fernão Lopes en el primer capítulo de su crónica sobre D. João I criticó la intencionalidad del discurso de Pedro López de Ayala; a pesar de que no lo citó directamente se sobreentiende que estaba refiriéndose a él cuando señaló la existencia de un "historiador castellano que escribió sobre el Reino de Portugal, que a pesar de ser hombre de buena autoridad se desvió del buen camino a la hora de escribir sobre D. João I de Portugal dada su desafección hacia su figura"4. A partir de entonces, la historiografía portuguesa solamente centró su atención en Ayala para criticar su versión alternativa de los hechos acontecidos en el reinado de D. João I de Portugal, siempre escudándose en esa desafección de los castellanos. José Soares da Silva en 1732 señaló que el autor de las crónicas castellanas afirmaba cosas sin fundamento ${ }^{5}$, mientras que Francisco de São Luis, más conocido como el cardenal Saraiva, en la primera mitad del siglo XIX directamente dudó de su autoridad al no contar con documentación que apoyase su narración 6 .

3 El discurso alternativo ayaliano apenas tiene presencia en las últimas dos grandes biografías de D. João I, la de Damião Lopes en $1917^{7}$ y la de Maria Helena da Cruz Coelho en $2005^{8}$. Esa falta de hueco no tiene su razón de ser en el desconocimiento del discurso castellano, sino que se debe a la preocupación de la historiografía lusa en atender y criticar exclusivamente al mito construido en la historiografía portuguesa en torno a la figura de este monarca, ese que Margarida Garcez Ventura fue desgranando en su obra $O$ messias de Lisboa ${ }^{9}$.

4 En la actualidad el discurso castellano, el de la legitimidad contraria a D. João I de Portugal, cobra interés dentro de las nuevas tendencias de la historia política bajomedieval, que ponen su acento en la cuestión de la legitimidad dinástica. En este sentido cabe destacar el hecho de que el macroproyecto Gènese de l'État Moderne dirigido por Jean Philippe Genet haya puesto sus miras en las cuestiones de legitimidades contrarias a través de los resultados del congreso ¿Golpes de estado a fines de la Edad Media? Fundamentos del poder político, celebrado en la madrileña Casa de Velázquez en $2002^{10}$. Una cuestión que más recientemente fue abordada por la historiografía portuguesa al acoger el cuarto congreso de la Royal Studies Network que llevó por título Dynastic changes and legitimacy y tuvo lugar en la Universidade de Lisboa en 2015; y al celebrar el congreso Debuerit Habere Regnum. Deponer y proclamar reyes en la Edad Media en esa misma universidad al año siguiente.

5 Nuestra intención es la de rescatar el discurso castellano en las diversas fuentes: crónicas, epístolas, documentación diplomática, sigilografía, numismática..., para conocer su fundamentación, sus vehículos de difusión y su pervivencia a lo largo del tiempo. De esta forma analizaremos cuestiones como la defensa oficial de los derechos soberanos sobre el trono luso de Juan I de Castilla y Beatriz de Portugal, el no recocimiento de la soberanía del denominado adversario D. João I de Portugal, la construcción de un personaje cuyos 
orígenes y acciones lo hacían indigno de ser considerado monarca de Portugal, las réplicas de ese discurso en la acción de gobierno del infante Fernando como segundo del reino, regente y monarca de Aragón; y la reutilización del discurso en posteriores momentos de enfrentamiento luso-castellano como la Guerra de Sucesión Castellana.

\section{La posición oficial de la monarquía castellana: de adversario a monarca reconocido}

6 La posición oficial de la monarquía castellana desde el fallecimiento de Fernando I de Portugal en 1383, fue la de reivindicar los derechos sucesorios de su hija Beatriz, esposa de Juan I de Castilla, y no reconocer la proclamación de D. João I de Portugal en las cortes de Coimbra de $1385^{11}$. Con tal fin, todo el aparato oficial del reino (documentación, sellos, monedas, ...) se adaptó para reflejar a los monarcas castellanos como soberanos del territorio luso. Igualmente en aquella documentación, en la que se tenía que identificar al monarca portugués de facto, no podía ser titulado como D. João I de Portugal, sino que se utilizó una terminología específica que daba a entender ese no reconocimiento.

7 Como señalamos, Juan I de Castilla se hizo titular constantemente en la documentación emitida por su cancillería regia como "Don Juan, por la gracia de Dios Rey de Castilla, de León, de Portugal, de Toledo, de Gallizia, de Sevilla, de Córdova, de Murçia, de Iahen, del Algarbe, de Algezira, et sennor de Vizcaya e de Molina" ${ }^{12}$. Asimismo tenemos constancia del empleo de dicha titulación y de iconografía en otros dos medios propagandísticos como la moneda y el sello. Por una parte, disponemos del testimonio de la acuñación de moneda con el emblema "Ioanis Rex Cast Legionis Portvg" en un cornado de vellón de una ceca fronteriza como era Zamora ${ }^{13}$. Por otra parte, tenemos conocimiento de la existencia de varios ejemplos de sellos (en sus diversas materialidades: plomo, cera, placa, signo rodado) con la leyenda "Sigilvm Ioanis Dei Gratie Regis Castel.Leg.Portugaliae" y con el empleo de las armas del reino de Portugal junto con las de la corona de Castilla y León ${ }^{14}$.

8 La utilización de la nominación y de los emblemas del reino de Portugal por parte de Juan I de Castilla era esencial para hacer constar sus derechos regios sobre el territorio luso, era lo que el cronista Duarte Nunes de Leão describió como parte del ejercicio efectivo de la soberanía: "Mandou abrir novos sellos das armas de Portugal, e Castella, partindo o escudo pollo meido; e na primeira ametade estavão as insignias de Castela, e Leão, de Portugal, de Toledo, de Galiza, etc. E allí en Santarem mandou lavrar moeda com o cunho daquellas insignias"15. La nueva nominación debía ser respetada por sus súbditos tanto al dirigirse al monarca como en los actos públicos; de esta forma observamos cómo por ejemplo fue empleada en el pontificial encargado por Juan de Villacreces, obispo de Calahorra y Santo Domingo de la Calzada (1382-1394) ${ }^{16}$.

9 La nominación oficial fue también reconocida por su principal aliado externo, Carlos VI de Francia, que en la documentación de su cancillería se refería al soberano castellano en estos términos: "carissimi fratris nostri Castelle, Legionis et Portugalie regis"17. Asimismo el pontífice aviñonés Clemente VII, candidato apoyado por el soberano castellano, también reconoció a Juan I de Castilla como "Castelle et Legionis ac Portugalie regi illustri" en una bula otorgada en abril de $1386^{18}$, aunque inmediatamente después eliminó la referencia al reino portugués a partir de otra bula promulgada en julio de $1386^{19}$. Por el contrario y como es lógico, los aliados externos de D. João I de Portugal no reconocían oficialmente los derechos de Juan I de Castilla al trono luso. El pontífice romano Urbano VI, que no era 
reconocido por el monarca castellano, siempre se refirió a Juan I de Castilla como "rege Castelle et Legionis", como podemos observar en la bula de cruzada en la que el pontífice romano autorizaba a iniciar una guerra santa en contra del monarca castellano a fin de acabar con su posición cismática ${ }^{20}$.

En ese sentido se entiende que Juan I de Castilla no emplease su titulación como monarca luso en el acuerdo de 1388 con Juan de Gante para el matrimonio de sus hijos Enrique de Castilla (futuro Enrique III) y Catalina de Lancaster, que ponía fin a las pretensiones de los Lancaster al trono castellano. En ese documento el monarca castellano aparece simplemente como "Johannis Castelle regem" ${ }^{21}$, lo que suponía rebajar sus pretensiones al trono portugués en aras de llegar a un pacto con los Lancaster ingleses, aliados de D. João I de Portugal ${ }^{22}$. Del mismo modo que el monarca castellano, su esposa y reina Beatriz apareció titulada como reina de Castilla, León y Portugal en los documentos emitidos por su cancillería ${ }^{23}$, en unos reales de plata ${ }^{24} \mathrm{y}$ en dos sellos de cera ${ }^{25}$. Una prelación de títulos idéntica a la de su esposo que según César Olivera Serrano nos indica su sumisión hacia el soberano castellano, demostrando su papel de depositario y administrador de los derechos de sucesión de la reina sobre el trono portugués ${ }^{26}$.

Cuando Juan I de Castilla fallece en octubre de 1390, su sucesor Enrique III de Castilla no mantiene la nominación como monarca luso por expreso deseo de las últimas voluntades de su padre. La causa era que el nuevo monarca era fruto del matrimonio anterior de Juan I de Castilla con Leonor de Aragón, y no de las últimas nupcias de su padre con Beatriz de Portugal, las cuales además no dejaron descendencia alguna. Algo que no significaba que el monarca castellano cejase en su lucha por defender los derechos dinásticos de su madrastra, la cual sí mantuvo su nominación como reina de Castilla, León y Portugal hasta sus últimos días, incluso cuando la monarquía castellana había reconocido a D. João I como monarca legítimo de Portugal ${ }^{27}$.

12 Anteriormente a ese reconocimiento, en la documentación emitida por la cancillería castellana se utilizó el término "adversario" para designar a D. João I de Portugal, ya fuese en las órdenes dadas a los municipios ${ }^{28}$, en correspondencia con el aliado Carlos VI de Francia ${ }^{29} \mathrm{o}$ incluso en las ratificaciones de las treguas con el propio soberano luso no reconocido ${ }^{30}$. Ésto último supone una contradicción porque el hecho en sí mismo de admitirlo como interlocutor en la negociación de unas treguas, significaba el reconocimiento de facto de su condición de soberano portugués. Para evitar ese reconocimiento tácito, en ocasiones el discurso de la documentación diplomática va más allá y llega a discernir entre el "adversario" y el reino de Portugal, como podemos ver en la dirección del documento de concesión de treguas por parte de Enrique III de Castilla en $1402^{31}$. Con este recurso se planteaba disociar al pretendido usurpador de un reino que no le correspondía y que tenía secuestrado.

13 Ese término "adversario" fue en ocasiones también empleado por aquellos monarcas y señores que se dirigían a los castellanos, como fue el caso de la epístola enviada en 1398 por Felipe II de Borgoña a Enrique III de Castilla en la que se hace mención al enfrentamiento dinástico de la siguiente manera: "ce qui touche la guerre de vous et de l'adversaire de Portugal" ${ }^{32}$, o de la carta enviada por Martín I de Aragón a Enrique III de Castilla en 1400 para felicitarle por la victoria obtenida sobre su adversario ${ }^{33}$. Sin embargo, en otras ocasiones no sucedió lo mismo, como fue el caso de la epístola enviada por Luis de Valois, duque de Orleans, a Enrique III de Castilla para ofrecerle ayuda militar en el contexto de la toma de Badajoz por parte de los portugueses en 1396. En dicha epístola se reconoce al soberano luso cuando se remite a las empresas militares del 
monarca castellano: "touchant la matiere d'aucunes vos besoignes que vous avez faire au roy de Portugal pour cause de votre guerre" ${ }^{34}$. No podemos conocer con exactitud la razón de esta actitud del duque de Orleans, pero una causa posible podría ser una muestra de su rechazo al apoyo que el monarca castellano brindó a las pretensiones de la casa de Luxemburgo al trono del Sacro Imperio Romano, una familia con la que el duque estaba enfrentado por sus aspiraciones al trono de Hungria ${ }^{35}$.

Sin embargo, la terminología empleada por la cancillería castellana para designar a D. João I de Portugal se suavizó en la comunicación directa e informal a través de epístolas entre la administración regia castellana y el monarca luso de facto. De esta suerte, el doctor Antón Sánchez se dirigía a D. João I de Portugal como "muy grande, honrrado e excelente señor" en una carta enviada en 1403 para informarle sobre la confirmación francesa a las treguas luso-castellanas de 1402 y sobre una serie de ataques corsarios ingleses en Galicia ${ }^{36}$. No cabe duda de que el formato epistolar y la flexibilización de las relaciones luso-castellanas a partir de las mencionadas treguas permitían tal licencia al burócrata castellano.

15 A pesar de que el monarca castellano no reconocía formalmente al nuevo monarca portugués, se vio abocado a aceptarlo de facto con el fin de iniciar la negociación de las diversas treguas acaecidas entre la crisis sucesoria de $1383 \mathrm{y}$ el tratado de paz en 1411. Ésto daba lugar a que la diferentes partes en los acuerdos firmados entre las misiones diplomáticas de cada monarca defendieran su posición sobre quién era el soberano luso, lo que llegó a ocasionar que en el documento de las treguas de Monção de 1389 aparecieran simultáneamente dos reyes de Portugal: "dom Ioham pela graça de Deus rey de Portugal e do Algarve" (D. João I de Portugal) y "el rey de Castella, de Leom e de Portugal" (Juan I de Castilla) ${ }^{37}$.

La utilización del término "adversario" se mantuvo en la documentación oficial hasta la aprobación del Tratado de Paz de Ayllón de 1411, por el que el consejo de regencia de Juan II de Castilla aceptaba reconocer a D. João I como soberano de Portugal y apartarse activamente de la defensa de los derechos al trono de Beatriz de Portugal ${ }^{38}$ (la renuncia efectiva no llegó hasta el Tratado de Medina del Campo de 1432) ${ }^{39}$. Por ello en el propio Tratado de Paz de Ayllón de 1411 ya no se habla de "adversario", un vocablo que desde entonces desapareció y fue reemplazado por el de "rey don Iohan de Portugal e del Algarbe" ${ }^{40}$. Automáticamente, Carlos VI de Francia dando su aquiescencia al Tratado de Ayllón, también se refiirió a D. João I como "le roy de Portugal et d'Algarbe" ${ }^{41}$. En ese momento podemos señalar que la dinastía Avis quedaba oficialmente reconocida por las principales potencias políticas del momento.

\section{La construcción de un infame personaje a través de la crónica de Pedro López de Ayala}

17 La corona castellana tenía consciencia de que la propaganda en favor de sus derechos dinásticos sobre el Reino de Portugal, y en contra de las aspiraciones de D. João I de Portugal, debía mantener un discurso que sobrepasase el lenguaje técnico y formal de documentos, sellos y monedas. La fuente esencial para el conocimiento del discurso propagandístico es la crónica, instrumento narrativo de gran difusión y conservación, cuya intencionalidad básica es la defensa de los intereses dinásticos. 

Portugal contamos con una fuente cronística de excepcional importancia: las crónicas de Pedro López de Ayala correspondientes a los reinados de Juan I y Enrique III de Castilla. Ambas crónicas fueron redactadas por un testigo de primera mano al calor de los hechos acontecidos, lo que nos acerca más al discurso oficial de los soberanos castellanos en plena crisis y no a una construcción de memoria histórica posterior. El cronista Pedro López de Ayala, miembro de la administración castellana, fue apresado por los portugueses tras la derrota de Aljubarrota en 1385, para posteriormente ser liberado y volver al reino luso como embajador del monarca castellano en las negociaciones de las treguas de $1393^{42}$. ambos reinos en la década de los noventa del siglo XIV como de "poca amistanza que era entre el Regno de Castilla e de Portogal, é que estaban para aver guerra, o facer pleytesia a poca honra de Castilla, por maneras tales que los de Portogal veian" ${ }^{43}$. Si bien el cronista tenía la consciencia de que el conflicto no solamente existía con el monarca portugués al afirmar que "el maestre Davis e todos los de aquel regno eran enemigos de Castilla", sabía de la necesidad de dirigir sus miras contra su gobernante de facto que era descrito como "el enemigo capital de Castilla" ${ }^{44}$, y procedió a criticarle personalmente. Las críticas ayalianas acabaron siendo respondidas tiempo después por la crónica de D. João I de Fernão Lopes, un texto encargado entre 1440 y 1448 por el consejo de regencia de D. Afonso $\mathrm{V}$ al cronista oficial del reino. Este texto pretendía consolidar la imagen de la dinastía Avis en un momento de debilidad regia, en la que las alabanzas a su fundador eran fundamentales. A pesar de que una de las bases más importantes del texto de Fernão Lopes son las crónicas de Pedro López de Ayala, podemos detectar cambios fundamentales y lógicos a la hora de presentar la figura y los hechos de D. João I de Portugal.

La condición de ilegitimidad de D. João I de Portugal era una constante en el discurso de las crónicas. Pedro López de Ayala destacó sus lazos de parentesco en sus primeras apariciones inmediatamente posteriores al fallecimiento de D. Fernando I de Portugal para realzar su condición de bastardo. A partir de la narración de la proclamación de las Cortes de Coimbra de 1385 se centró sobre su condición de clérigo regular al resaltar la condición de maestre de una orden religiosa por encima de su nombre, al referirse a su persona con la expresión "el maestre Davis que se fazia llamar rey de Portugal" ${ }^{45}$, la cual posteriormente fue utilizada de forma distorsionada por Fernão Lopes ya que la puso en el discurso del propio Juan I de Castilla ${ }^{46}$. El soberano luso era consciente de que la condición eclesiástica era el principal obstáculo en sus aspiraciones regias, puesto que era un impedimento para contraer matrimonio, algo esencial para preservar una futura dinastía, una cuestión que era resaltada por Ayala en la narración del pacto entre Juan de Gante y D. João I de Portugal por el que le cedía la mano de su hija Filipa de Lancaster, en la que señala que la orden militar de Avis era una orden regular cisterciense como lo era la orden militar de Calatrava en Castilla ${ }^{47}$. El discurso de contestación de D. João I que fue articulado en las "razões" de João das Regras presentadas en las Cortes de Coimbra de 1383 se basó en que el pontífice tenía potestad para declarar los casos en los que el derecho divino impide el contrato matrimonial ${ }^{48}$. El proceso de obtención de la dispensa papal requirió de varias embajadas ${ }^{49}$, pero la consecusión de las bulas pontificias de dispensa en $1391^{50}$ hizó que el discurso legitimador de la dinastía Avis utilizase esos documentos, los cuales incluso fueron traducidos al portugués en la crónica de Fernão Lopes $^{51}$. El monarca portugués es descrito en la crónica de Ayala como un dirigente que 
era capaz de utilizar todas las artimañas para hacerse con el poder, vacilante, intrigante, oportunista, cobarde, pérjuro..., toda una suerte de cualidades propias de un perfecto gobernante maquiavélico opuestas a los valores propios del código caballeresco que eran utilizados por el cronista para enjuiciar los actos de los monarcas ${ }^{52}$.

La primera aparición de D. João I de Portugal en la crónica de Juan I de Castilla coincide con la muerte de D. Fernando I de Portugal. Ayala subrayó que fue el primero en comunicar lo sucedido al monarca castellano y en reclamar su pronta llegada a Portugal para tomar el reino ${ }^{53}$, cuestión que Fernão Lopes omitió deliberadamente en su relato ${ }^{54}$. Este hecho sirvió a Ayala para reprochar el cambio de posición política del soberano luso de interpelar al monarca castellano para tomar el trono portugués a ser proclamado como rey de Portugal. Ayala obviaba que la postura inicial es comprensible en el contexto de que el bastardo regio quería evitar a toda costa que su enemiga política, la reina madre Leonor Teles, llegase a dirigir los designios políticos en el territorio portugués como reina regente ${ }^{55}$.

Lo que parece un simple cambio de postura política vuelve a ser planteado en la crónica de Ayala en términos de incumplimiento de juramento, puesto que se narra cómo Juan I de Castilla en las vísperas de la batalla de Aljubarrota recordó al maestre de Avis que su rebeldía suponía la ruptura de la lealtad prometida en las bodas entre el monarca castellano y Beatriz de Portugal ${ }^{56}$, hecho que ni siquiera fue ocultado por Fernão Lopes ${ }^{57}$. En virtud del juramento el maestre de Avis se comprometía a respetar que en el caso del fallecimiento sin descendencia masculina de D. Fernando I de Portugal, la corona portuguesa se trasmitiera a Beatriz de Portugal y que su marido Juan I de Castilla pudiera ejercer como regente, por lo que su ruptura fue uno de los argumentos de los castellanos para calificarle como pérjuro ${ }^{58}$.

Para el cronista castellano el soberano luso era una persona poco cumplidora con los pactos alcanzados, cuestión que no se limitaba al incumplimiento de lo acordado con sus enemigos castellanos, sino que se hizo extensible a sus propios aliados. En este sentido Ayala describió cómo Juan I de Portugal no respetó el acuerdo con Juan de Gante, duque de Lancaster, por el que solamente podía casarse con su hija Filipa de Lancaster a partir de la obtención de la dispensa papal requerida, el monarca luso se anticipó a la acquiescencia pontificia para así poder chantajear a Juan de Gante y exigirle en concepto de dote el pago de los gastos que supuso la participación del ejército portugués ${ }^{59}$ en su fallida invasión al reino castellano en $1387^{60}$. Por el contrario, Fernão Lopes no niega que en el acuerdo inicial de matrimonio se exigiese la dispensa papal ${ }^{61}$ y que la ceremonia se realizó sin ese requisito previo ${ }^{62}$, pero no refleja a posteriori una mala sintonía con el duque de Lancaster y mucho menos la exigencia de un pago en concepto de dote, sino todo lo contrario porque describe como D. João I de Portugal obtuvo los fondos necesarios para poder sufragar los gastos de las tropas inglesas ${ }^{63}$.

Por otra parte, el cronista fue describiendo cómo a partir del asesinato del favorito de la regente, João Fernandes Andeiro, conde de Ourém, el maestre de Avis fue ganando progresivamente el afecto del pueblo de Lisboa, primero como regente a la espera del regreso del legítimo infante Juan (hijo de Pedro I de Portugal y hermanastro del maestre de Avis, que estaba preso en manos de Juan I de Castilla ${ }^{64}$ ), y después como monarca ante la imposibilidad de tal liberación ${ }^{65}$. Fernão Lopes también consideró el asesinato de João Fernandes Andeiro como el punto de partida del ascenso de D. João I de Portugal, por lo que lo estableció como inicio de la narración de la crónica del mencionado soberano ${ }^{66}$. 

de Lisboa, esas masas que clamaban venganza cuando pensaban que su candidato, el propio João, fue asesinado en lugar del odiado favorito de la regente, y que después provocaron la muerte del obispo de Lisboa, el castellano Martinho de Zamora ${ }^{67}$. Pero López de Ayala compartía con la crónica de Fernão Lopes que el soberano portugués representaba los intereses de los sectores urbanos, entre los que se encontraba tanto la burguesía de los "homens bons" como los sectores populares que el cronista luso define como "arraia-miúda dos menesterais e ventres ao sol" (el populacho menudo de los artesanos y los estómagos al sol) ${ }^{68}$. Sin embargo, a diferencia del cronista luso, Ayala no lo consideraba como algo positivo, sino todo lo contrario, puesto que esas ambiciones eran contrarias a las legítimas de la nobleza portuguesa, alineada con las pretensiones de Juan I de Castilla. Con este discurso puede entenderse que Ayala los denominara como grandes caballeros de Portugal en un listado con una treintena de nombres de señores, miembros de órdenes militares y alcaides portugueses que apoyaron las pretensiones castellanas ${ }^{69}$. colaboraban con la causa castellana eran presentados con adjetivos como bueno, honrado, de buena voluntad..., que apenas fueron utilizados en las crónicas de este autor. Un ejemplo de ello es Afonso Correia, obispo de Guarda ${ }^{70}$, clementista y sufragáneo de Santiago de Compostela, que fue descrito como "ome bueno e honrado e con buena voluntad" cuando ofreció su ciudad como base de la primera entrada de los castellanos en $1383^{71}$, lo que Ayala omitió y Fernão Lopes matizó es que su compromiso con la causa de Juan I de Castilla derivaba de su cargo de chanceler de Beatriz de Portugal ${ }^{72}$. Otro ejemplo es el de Arias Gómez de Silva, que para el cronista era un "caballero muy bueno" cuando narraba su resistencia al asedio por parte de los partidarios del recién nombrado D. João I de Portugal sobre su villa de Guimarães ${ }^{73}$. Por su parte Fernão Lopes también relató los sucesos de Guimarães desde otra perspectiva, la de la resistencia de Arias Gómez de Silva, un valiente caballero de orígenes castellanos y no portugueses, que finalmente se vió traicionado por los castellanos al negarle los refuerzos solicitados y que no tuvo más remedio que entregar la ciudad a D. João $\mathrm{I}^{74}$. En definitiva, el discurso cronístico de Pedro López de Ayala nos resalta que D. João I de Portugal no era el monarca óptimo no solamente por sus condiciones de bastardía y de eclesiástico, sino también por su personalidad y su modo de dirigir las riendas del reino luso. Decadas después, Fernão Lopes utilizó las crónicas de Pedro López de Ayala para un objetivo contrario, el de ensalzar la figura de D. João I, para ello aplicó diversos recursos como la omisión de información o la reinterpretación de los mismos hechos. En definitiva, tenemos dos cronistas relatando los mismos hechos al servicio de cada una de las dos dinastías, y el resultado son dos imágenes diferentes de un mismo personaje.

\section{La mano dura del infante Fernando de Castilla contra el traidor adversario.}

La casual conservación en diversos archivos de una serie de interesantes epístolas escritas por el infante Fernando, hermano de Enrique III de Castilla (futuro Fernando I de Aragón) nos permite saber cuál era el discurso seguido en referencia a D. João I de Portugal a través de un personaje de importancia capital en la corte castellana. El infante Fernando de Castilla era la personalidad de la familia real castellana que podía mantener la posición más dura contra el soberano luso, puesto que a diferencia de su hermano Enrique III de 
Castilla, no debía mantener la moderación propia de un monarca, ni estaba casado con Catalina de Lancaster, hermana de la reina portuguesa Filipa de Lancaster. Asimismo, en aquel momento no tenía posibilidad alguna de casar a sus descendientes con los de la dinastía Avis, los infantes de la ínclita geração, a causa de la prohibición impuesta por su propio hermano ${ }^{75}$.

Dadas estas condiciones, no parece de extrañar que el infante Fernando de Castilla se refiriese a D. João I de Portugal como "traydor adversario" cuando comunicó a su hermano Enrique III de Castilla que aceptaba su decisión en las negociaciones llevadas a cabo en $1399^{76}$. Posteriormente el infante, siguiendo su rol de "poli malo" en las negociaciones luso-castellanas, se permitió la licencia de comunicar a la embajada portuguesa que acudía a la corte castellana para negociar las treguas de 1402 que no iba a ser recibida, señalando que seguían órdenes de su monarca para engañar a su hermano Enrique III de Castilla ${ }^{77}$. El discurso del infante Fernando de Castilla parece extraído de la propia crónica de Pedro López de Ayala, y es que parece que no existe diferencia alguna entre el discurso propagandístico oficial y el empleado en su comunicación epistolar en su etapa como segundo del reino. El infante dibujó a D. João I de Portugal como un personaje de poca palabra, que no dudaba en recurrir a sucias artimañas para conseguir su propio beneficio como gobernante. Por ello su acción política posterior giraría en torno a la idea de desconfianza.

Cuando Enrique III de Castilla fallece prematuramente en la navidad de 1406 se estableció una regencia compartida entre la reina madre Catalina de Lancaster y el infante Fernando de Castilla. En este contexto tendremos un enfrentamiento entre ambos regentes sobre las relaciones luso-castellanas: mientras la reina madre era defensora de un acercamiento, el infante albergaba suspicacias sobre las intenciones del soberano luso. En este sentido el infante fue reticente a la firma del Tratado de Paz de Ayllón de 1411 y se opuso exitosamente a una posible intervención portuguesa en la campaña de Granada $(1408-1412)^{78}$.

30 La muerte sin descendecia de Martín I de Aragón abrió la posibilidad de que el regente Fernando de Castilla pudiera ocupar el trono aragonés, como finalmente sucedió tras la aprobación del Compromiso de Caspe de junio de 1412. El nuevo monarca castellano se encontró gobernando un reino extranjero y con la oposición de otros candidatos que vieron frustradas sus opciones; especialmente importante fue la revuelta del conde Jaume II de Urgel que Fernando I de Aragón tuvo que sofocar con el asedio de Balaguer y con el posterior encarcelamiento del conde en el castillo de Xàtiva. En su etapa como monarca aragonés continuó la actitud de sospecha hacia el monarca portugués, al que acusaba de participar en socorro del conde de Urgel en su encierro en Balaguer ${ }^{79} y$ de que la armada que estaba preparando para finalmente conquistar Ceuta tendría como objetivo liberarle del castillo de Xàtiva y apoyarle en sus reivindicaciones, llegando a casar a uno de los infantes portugueses con una de las hijas del conde ${ }^{80}$. En los múltiples rumores que circulaban sobre el destino de la armada portuguesa también se apuntaban una posible intervención en Nápoles o en Sicilia, territorios de influencia aragonesa, e incluso los más aventurados se atrevieron a señalar la posibilidad de una confederación entre Catalina de Lancaster con D. João I de Portugal frente a Fernando I de Aragón ${ }^{81}$. El monarca aragonés, haciendo gala de su desconfianza ante su homólogo portugués, inició un despliegue de medios para tener informaciones sobre la cuestión que incluyeron la representación diplomática y el espionaje ${ }^{82}$. 
31 Sin embargo, Fernando como gobernante tuvo que moderar su discurso con respecto a D. João I de Portugal. Incluso vemos que en la correspondencia cruzada con el monarca portugués el infante, ya como monarca aragonés, se refiere a él como "rey muy caro y muy amado tío" y le desea buenos augurios en estos términos: "a quien querríamos que diese Dios tanta vida, salud e buena ventura quanta vos mismo querriades" ${ }^{83}$. Al mismo tiempo, tanto D. João I de Portugal como Filipa de Lancaster se dirigían hacia el monarca aragonés como "muy nobre e mui honrrado e poderos prinçipe, nosso muy amado e muy preçado sobrino dom Fernando, polla graça de Deus rey d'Aragom e de Cezilia" ${ }^{84}$ o como "muy amado e muy preçado rey d'Aragom, sobrino amigo" ${ }^{35}$. Podemos señalar que existió una creación de parentesco ficticio dado que Fernando I de Aragón no era sobrino de los reyes de Portugal, pero que posiblemente se estableció en virtud de su posición como representante de Juan II de Castilla, sobrino de la reina de Portugal.

En definitiva, uno de los rasgos propios de la trayectoria política de Fernando en sus tres estadios (infante de Castilla, regente de Castilla y monarca de Aragón) fue su constante oposición a D. João I de Portugal. El discurso y la actuación política de Fernando fueron importantes para la construcción de la imagen negativa del soberano portugués en Castilla. Por todo ello Luis Suárez Fernández llegó a calificarle de anti-portugués ${ }^{86}$, una afirmación inexacta puesto que en realidad solamente albergaba suspicacias acerca de la dinastía que gobernaba el reino vecino.

\section{La imagen de D. João I de Portugal en la construcción historiográfica castellana del siglo XV}

D. João I de Portugal afrontó el tramo final de su reinado con el reconocimiento castellano a su proclamación y el espaldarazo internacional de la exitosa empresa de la conquista de Ceuta. Su longevidad le permitió sobrevivir a todos aquellos protagonistas del enfrentamiento luso-castellano: Juan I de Castilla (+1390), Enrique III de Castilla ( $† 1406)$, Pedro López de Ayala (†1407), Fernando I de Aragón (†1416), Beatriz de Portugal (†1420). Esto podía ser ápice para que el discurso castellano fuera suavizado. Sin embargo, el encargado de realizar las dos primeras partes de la crónica de Juan II de Castilla entre 1406 y 1435, Álvar García de Santa María, también tenía una edad avanzada que le había hecho ser espectador del enfrentamiento luso-castellano ${ }^{87}$. Asimismo, como miembro de la familia conversa de los García de Santa María, era una personalidad de indudable cercanía a Fernando I de Aragón ${ }^{88}$, protagonista principal de la primera parte de la crónica de Juan II de Castilla como encargado de la empresa militar granadina ${ }^{89}$.

Álvar García de Santa María en su crónica se refirió a D. João I de Portugal como "rey de Portugal”, puesto que no reconocerlo no tendría sentido alguno en la situación política posterior al Tratado de Ayllón de 1411. La reivindicación de los derechos castellanos al trono portugués quedó apartada del discurso cronístico castellano y su nuevo objetivo era el de relativizar el éxito de la conquista de Ceuta, que había dejado en un segundo plano todos los triunfos de Fernando de Antequera en su campaña contra los nazaríes granadinos. Con tal fin se puso en valor la participación de marineros castellanos en la empresa militar y se subrayaron las consecuencias negativas del mantenimiento de la plaza norteafricana para la economía portuguesa ${ }^{90}$. Frente a la imagen de estratega exitoso que presentó posteriormente en la Crónica da Tomada de Ceuta de Gomes Eanes de Zurara $^{91}$ de 1450 , la crónica castellana refleja la imagen de un gobernante poco realista 
que, a pesar de conseguir apoderarse de Ceuta, no tuvo en consideración todas las consecuencias negativas para el reino:

"E esta tomada de Çeuta que tomaron los portogaleses fue muy grande armada, e el reyno es pequeño, e con las maneras quel rey lo fizo fue muy dañoso a los moradores del reyno de Portogal. Porque por ocasión desta armada, e de mantener a Çebta, hera muy despachados de su rey para esto. Tanto que lo avían por muy grande sentimiento; e muchos dellos le dexaron la tierra, e fueron a poblar otros reynos" $"$.

La figura de D. João I de Portugal no aparece mencionada ni en la Segunda parte de la Crónica de Juan II atribuida a Fernán Pérez de Guzmán que cubre el espacio temporal comprendido entre $1435-1454^{93}$, ni en la Crónica del Halconero de Juan II, Pedro Carrillo de Huete, de 1441 que cubre el arco cronológico comprendido entre 1420 y $1441^{94}$. Sin embargo, la Refundición de la Crónica del Halconero de Juan II de Lope de Barrientos de $1454^{95}$ situa el inicio de la narración en 1395 coincidiendo con el final de la crónica de Enrique III de Pedro López de Ayala, esto supone la reaparición de D. João I de Portugal en la crónistica castellana como el monarca traidor que quebrantó las treguas de 1393 con la tomada de Badajoz de $1396^{96}$.

El ascenso al trono de D. Enrique IV de Castilla en 1454 y su matrimonio con Juana de Portugal, hermana del monarca D. Afonso V de Portugal en 1455, significaron la culminación de una política de acercamiento iniciada por el soberano luso tras su victoria en la batalla de Alfarrobeira en 1449, la cual perduró hasta la batalla de Toro en $1476^{97}$. En este periodo la monarquía portuguesa para llevar a cabo su política procastellana realizó un esfuerzo propagandístico basado en realzar la importancia de las campañas norteafricanas portuguesas y en mejorar la reputación de la dinastía Avis, pruebas de ello son la versión traducida al latín en 1460 por Mateo Pisano de la Crónica da Tomada de Ceuta conocida como De Belli Septensi ${ }^{98}$, y un panegírico datado entre 1461 y 1462 sobre la familia real portuguesa escrito en castellano por Alonso de Cordoba bajo el patronazgo del condestable Don Pedro de Portugal ${ }^{99}$ que lleva por título Conmemoraçión breve de los muy insignes y virtuosos varones que fueron desde el magnifico rey don Juan el primero fasta el muy esclarecido rey don Alfonso el quinto. En el apartado de la figura de D. João I de Portugal de este último texto se destaca su nobleza, su valentía y sus dotes de mando ("No fue desde los godos tan esforçado caudillo") ${ }^{100}$. La versión más amable de la figura de D. João I ofrecida por la propaganda portuguesa aparece en dos crónicas castellanas del reinado de Enrique IV, el Memorial de Diversas Hazañas de Enrique IV de Diego de Valera datado entre 1467 y $1481^{101}$, y la Gesta Hispaniensia de Alonso de Palencia, fechada en $1481^{102}$. En la primera aparece recordado como el gran conquistador de Ceuta en el momento de registrar noticias sobre las empresas africanas de D. Afonso V de Portugal ${ }^{103}$, y en la segunda es evocado como el rey de inolvidable recuerdo ${ }^{104}$.

Sin embargo, el fracaso de la política procastellana de D. Afonso V de Portugal con la victoria de los Reyes Católicos en la Guerra de Sucesión Castellana supuso una vuelta al enfrentamiento entre ambas monarquías ${ }^{105} \mathrm{y}$ la recuperación de la imagen negativa del fundador de la dinastía Avis. Fernando del Pulgar en su Crónica de los Reyes Católicos escrita en los últimos años del siglo $\mathrm{XV}^{106}$ rescató el discurso de la crónica de Pedro López de Ayala para defender los intereses de los Reyes Católicos; de esta forma, D. João I de Portugal vuelve a ser nombrado como "maestre de Avis" y dibujado como el usurpador, que a pesar de ser fraile profeso y bastardo, aprovechó la connivencia de los portugueses para ser proclamado rey de Portugal. Sin embargo, Fernando del Pulgar utilizó en su discurso rasgos propios de un discurso protonacionalista al señalar que "los portugueses 
eligieron e quisieron por su rey al maestre de Avis, abuelo deste rey de Portugal, aunque era frayle profeso e bastardo, antes que sofrir por rey a onbre castellano, caso que era legítimo", obviando que en la crónica de Pedro López de Ayala se hace constante mención a aquellos portugueses "buenos" que defendieron la causa legítima de Juan I de Castilla ${ }^{107}$. La intención del cronista, al rescatar el discurso ayaliano y darle un barniz protonacionalista, era exhortar a los castellanos para que apoyasen a los Reyes Católicos como herederos legítimos de la dinastía castellana Trastámara frente a una dinastía extranjera como la de los Avis.

\section{Conclusiones} Portugal y a la pérdida de los derechos de sucesión de Juan I de Castilla, no solamente obligaron a los monarcas castellanos a mantener una larga situación de enfrentamiento que se prolongó a lo largo de tres décadas, sino que además tuvieron que crear un discurso legitimista con el fin de reivindicar los derechos al trono portugués y en detrimento del usurpador de tales intereses. Este discurso que giro en torno a la deslegitimación del golpe de estado de D. João I de Portugal tuvo una enorme vigencia y se prolongó más allá del conflicto inicial entre ambas dinastías, a pesar de que desapareció en las décadas centrales del siglo XV por el acercamiento entre los dos reinos, volvió a reaparecer con tinte protonacionalistas a partir el enfrentamiento en la Guerra de Sucesión Castellana.

El discurso tuvo dos vertientes: una legal y otra historiográfica. Tenemos constancia de la perspectiva legal tanto en instrumentos de aparato (monedas y sellos) como en los documentos diplomáticos castellanos $\mathrm{y}$, por extensión, en los de sus aliados externos, en los que se titula a Juan I de Castilla y a Beatriz de Portugal como soberanos del reino luso y en los que se hace referencia a D. João I de Portugal como el adversario. Una política lógica de no reconocimiento oficial que se prolongó hasta la ratificación del Tratado de Ayllón de 1411, pero que contrastaba con el reconocimiento de facto al considerarlo como parte valida en las negociaciones de treguas anteriores.

Desde la vertiente historiográfica el discurso se centró en desacreditar a D. João I como gobernante, tanto por sus condiciones personales, que impedían su acceso al trono (la bastardía o la condición de fraile profeso de la orden de Avis), como por su actuación política basada en la traición, el perjurio, la intriga, la vacilación, el oportunismo o la cobardía...; todas ellas características impropias de un buen gobernante para la teoría política de la época, basada más en el idealismo que en el realismo político.

41 En definitiva, las fuentes castellanas ofrecen una imagen bien distinta de las portuguesas en torno a una de las figuras más importantes de la historia lusa como es D. João I de Portugal. Contrasta enormemente el discurso luso, propio de un proceso de legitimación de un golpe de estado y de una nueva dinastía, con la propaganda castellana, cuya dirección era totalmente opuesta hacía la deslegitimación de esa nueva situación de facto, antagónica a sus intereses. Frente al rey de "buena memoria", también conocido como "mesias de Lisboa" al ser mandado por la divinidad como garante de las esencias del pueblo portugués frente al intervencionismo castellano, tenemos al "adversario", ese usupador "que se fazia llamar rey de Portugal", dispuesto a utilizar cualquier clase de artimañas con tal de ser reconocido como soberano frente a los derechos legítimos de su medio sobrina Beatriz de Portugal. 
versión de un D. João I de Portugal como una suerte de gobernandor maquiavélico dada por las fuentes castellanas debe ser atendida por la historiografía portuguesa, pudiendo de esta forma alejarse en cierta manera del discurso hagiográfico de Fernão Lopes o de Gomes Eanes de Zurara, y enriqueciendo la visión del primer monarca de la dinastía Avis, un personaje con mil caras que ha sido reivindicado por diferentes grupos de interés, tanto para bien como para mal.

\section{BIBLIOGRAFÍA}

Fontes manuscritas

Archivo Secreto Vaticano

Registra Lateranensia, 12, 10v.-12v.

Registra Supplicationum, 90, 55v.-60v.

Registra Supplicationum, 99, 50v.

Registra Supplicationum, 100, 71r.-73r.; 73v.-79r.

Registra Supplicationum, 102, 142r., 240r.

Registra Supplicationum, 103, 50r.-50v.

Registra Supplicationum, 104, 221v., 262r.

Registra Supplicationum, 116, 31v.-32r.

Registra Vaticana, 297, 9r., 75v.

Registra Vaticana, 310, 343v.-344v.

Archivo General de Simancas

Diversos de Castilla, legajo 11, documento 7.

Estado, Castilla, legajo 1-1ํㅜ 73 r.

Estado, Castilla, legajo 1-2º, 2r.

Libros De Privilegios y Confirmaciones, libro 299, 12r.

Patronato Real, legajo 49, documento 3.

Patronato Real, legajo 49, documento 4.

Patronato Real, Legajo 52, documento 4.

Biblioteca Capitular y Colombina de Sevilla

Manuscritos, manuscrito BB 149-3, 1v.

Arquivo Nacional da Torre do Tombo

Bulas, maço 5, documento 9

Gavetas, gaveta 18, maço 11, documento 4. 
Leitura Nova, livro 38 (Livro I dos Reis), fols. 8r.-9v.

Manuscritos, manuscrito 364, 457r.

Gabinete de História da Câmara do Porto

Vereações, libro 2, 47v. Editado como documento 119.

Archivo de la Corona de Aragón

Cartas reales, caja 1, Fernando I, número 3.

Cartas reales, caja 13, Fernando I, número 2490.

Cartas reales, caja 18, Alfonso V, número 1.

Registros reales, registro 2405, 56v., $142 \mathrm{v}$.

Registros reales, registro $2408,17 \mathrm{r}$.

Archives Nationales de la France

Série K, 1482, 12r. 13r.

Série J, 603, número 63.

Série J, 604, número 77.

Série J, 916, 4r.

Fontes impressas

AS GAVETAS da Torre do Tombo. Vol. IX. Ed. António da Silva Rego. Lisboa: Centro de Estudos Históricos Ultramarinos, 1971.

BARRIENTOS, Lope de - Refundición de la Crónica del Halconero. Ed. Juan de Mata Carriazo. Madrid: Espasa Calpe, 1946.

COLECCIÓN DE privilegios, franquezas, exenciones y fueros, concedidos a varios pueblos y corporaciones de la corona de Castilla copiados por orden de S. M. de los registros del Real Archivo de Simancas. Vol. V. Ed. Archivo General de Simancas. Madrid: Imprenta Real, 1830.

CÓRDOBA, Alonso de - Conmemoración breve de los reyes de Portugal. Un sermón castellano. Ed. Pedro Cátedra. Barcelona: Humanitas, 1983.

COSTA, Antonio Domingues de Sousa - Monumenta Portugaliae Vaticana. Vol. 2. Roma: Editorial Franciscana, 1970

LOPES, Fernão - Crónica de D. João I. 2 vols. Lisboa: Civilização editora, 1983.

LOPES, Fernão - Crónica de D. Fernando. Ed. Giuliano Macchi. Lisboa: Imprensa Nacional Casa da Moeda, 2004.

LÓPEZ DE AYALA, Pedro - “Crónica de Don Enrique III de Castilla". in Crónicas de los reyes de Castilla Don Pedro, Don Enrique II, Don Juan I y Don Enrique III por D. Pedro López de Ayala, chanciller mayor de Castilla, con las enmiendas del secretario Gerónimo Zurita. Vol. 2. Ed. Eugenio Llaguna Amirola. Madrid: Imprenta de Don Antonio de Sancha, 1780, pp. 345-582.

LÓPEZ DE AYALA, Pedro - “Crónica de Don Juan I de Castilla”. in Crónicas de los reyes de Castilla Don Pedro, Don Enrique II, Don Juan I y Don Enrique III por D. Pedro López de Ayala, chanciller mayor de Castilla, con las enmiendas del secretario Gerónimo Zurita. Vol. 2. Ed. Eugenio Llaguna Amirola. Madrid: Imprenta de Don Antonio de Sancha, 1780, pp. 123-344. 
MONUMENTA HENRICINA. Vol. I. Ed. Manuel Lopes de Almeida. Coimbra: Comissão executiva das commemorações do V centenário da morte do infante D. Henrique, 1960.

MONUMENTA HENRICINA. Vol. II. Ed. Manuel Lopes de Almeida. Coimbra: Comissão executiva das commemorações do V centenário da morte do infante D. Henrique, 1962.

NUNES DE LEÃO, Duarte - “Crónica del rey D. João I deste nome, e dos reys de Portugal o decimo”. in Cronicas del rey dom João de gloriosa memoria, o I deste nome, e as dos reys D. Duarte e D. Afonso $V$. Tomo I. Ed. Rodrigo da Cunha. Lisboa: Oficina de Jose de Aquino Bulhoens, 1780.

PALENCIA, Alonso de - Gesta Hispaniensa ex annalibvs svorvm diervm collecta. Tomo I, Libri I-V. Ed. Brian Tate y Jeremy Lawrence. Madrid: Real Academia de la Historia, 1998.

PULGAR, Fernando del - Crónica de los Reyes Católicos (Volumen I: la guerra de Granada). Ed. Juan de Mata Carriazo. Granada: Universidad de Granada, 2008.

VALERA, Diego de - Memorial de diversas hazañas. Crónica de Enrique IV. Ed. Juan de Mata Carriazo. Madrid: Espasa Calpe, 1941.

ZURITA, Jerónimo - Anales de la corona de Aragón. Vol. 5. Ed. Ángel Canellas López. Zaragoza: Institución Fernando el Católico, 1974.

Estudios

ÁLVAREZ PALENZUELA, Vicente Ángel - "El restablecimiento de la paz entre Castilla y Portugal 1402-1431". in HOMEM, Armando Luís de Carvalho; PIZARRO, José Augusto de Sotto Mayor; COSTA, Paula María de Carvalho Pinto (coords.) - Ibéria, quatrocentos / quinhentos, duas décadas de cátedra (1984-2006): homenagem a Luís Adão de Fonseca. Porto: Civilização Editora, pp. 47-90.

ÁLVAREZ PALENZUELA, Vicente Ángel - "Relations between Portugal and Castile in the Late Middle Ages - 13th-16th centuries”. E-Journal of Portuguese History 1 (2003), pp. 1-18.

BEIRANTE, Maria Ângela - As estruturas sociais em Fernão Lopes. Lisboa: Livros Horizonte, 1984. BRÁSIO, António - “As razões de João das Regras nas cortes de Coimbra”. Lusitania Sacra 3 (1958), pp. 14-15.

BRÁSIO, António - “Influência do cisma castelhano na solução da crise nacional de 1385". Lusitania Sacra 4 (1959), pp. 93-129.

CAETANO, Marcelo - A crise nacional de 1383-1385. Subsídios para o seu estudo. Lisboa-São Paulo: Verbo.

COELHO, Maria Helena da Cruz - D. João I, o que re-colheu Boa Memória. Lisboa: Círculo de Leitores, 2005.

CONTRERAS Y LÓPEZ DE AYALA, Juan de - "El cronista don Pedro López de Ayala y la historiografía portuguesa”. Boletín de la Real Academia de la Historia 102 (1933), pp. 115-157.

DAUMET, Georges - Étude sur l'alliance de la France et de la Castille au XIVe et XV siècles. París: Libraire Émile Bouillon, 1898.

DUARTE, Luis Miguel - Ceuta 1415, seiscentos anos depois. Lisboa: Horizonte, 2015.

ECHEVARRIA, Ana - "Catalina of Lancaster, the Castilian Monarchy and the coexistance". in COLLINS, Roger; GOODMAN, Anthony - Medieval Spain, culture, conflict and coexistance. Studies in Honour of Angus MacKay. New York: Palgrave Macmillan, 2002.

FARELO, Mário - “O percurso eclesiástico e político de Afonso Domingues de Linhares, bispo de Guarda (1364-1394) e de Segóvia (1394-1397)”. Estudios segovianos 60-112 (2013), pp. 277-323. 
FERNÁNDEZ DE CÓRDOBA MIRALLES, Álvaro - "Los emblemas de la conquista: armas y divisas de Juan I Trastámara ante la sucesión portuguesa”. Armas e trofeus, revista de história, heráldica, genealogia e arte 9 (2013), pp. 229-268.

FONSECA, Luis Adão da - "Alguns aspectos das relações diplomáticas entre Portugal e Castela em meados do século XV (1449-1456)”. Revista da Faculdade de Letras: História, I série, 3 (1972), pp. $51-112$.

FONSECA, Luis Adão da - "Una elegía inédita sobre la familia de Avis, un aspecto de la propaganda política en la Península Ibérica a mediados del siglo XV". Anuario de Estudios Medievales 16 (1986), pp. 449-463.

FORONDA, François; GENET, Jean-Philippe; NIETO SORIA, José Manuel - Coups d'État à la fin du Moyen Âge? Aux foundaments du pouvoir politique en Europe Occidentale. Madrid: Casa de Velázquez, 2005.

GÓMEZ REDONDO, Fernando - “Discurso y elocución en la Crónica de Juan II (1406-1434)”. Cahiers de linguistique et de civilisation hispaniques médiévales 27 (2004), pp. 225-248.

GONZÁLEZ SÁNCHEZ, Santiago - Fernando I, regente de Castilla y rey de Aragón. Gijón: TREA, 2012.

DUNPHY, Graeme (ed.) - Encyclopedia of the Medieval Chronicle. 2 vols. Leiden: Brill, 2010.

JARRY, Eugène - La vie politique de Louis de France, duc d'Orléans, 1372-1407. Paris: Alph. Picard, 1889.

LÓPEZ-MAYAN, Mercedes - "Los pontificales en Castilla durante la Edad Media: aproximación a una fuente de conocimiento histórico". in MIRANDA, Flavio; SEQUEIRA, Joana; FARIA, Diogo (eds.) - Incipit 2. Workshop de Estudos Medievais da Universidade do Porto. Porto: Universidade do Porto, 2014, pp. 141-143.

MATA CARRIAZO, Juan de - "La conquista de Ceuta en la crónica de Juan II de Álvar García de Santa María". Anais da Academia Portuguesa da História, II Série, 27 (1982), pp. 281-295.

MORENO, Humberto Baquero - "O valor da Crónica de Zurara sobre a conquista de Ceuta". in A abertura do mundo, estudos da história dos descobrimentos europeus. Em homenagem a Luís de Alburquerque Vol. II. Lisboa: Presença, 1987, pp. 191-202.

OLIVERA SERRANO, César - Beatriz de Portugal. La pugna dinástica Avís-Trastámara. Santiago de Compostela: Consejo Superior de Investigaciones Científicas, Xunta de Galicia, Instituto de Estudios Gallegos Padre Sarmiento, 2005.

ORIOL PERNAS, António - “Acuñaciones de Juan I de Castilla como rey de Portugal”. Nummus, Série I, 33 (1974), pp. 65-72.

PIMENTA, Alfredo - “As trégoas de Monção de 1389”. in Idade-Média (Problemas \& soluçoens). Lisboa: Edições Ultramar, 1946.

RUSSELL, Peter Edward - A intervenção inglesa na Península Ibérica durante a Guerra dos Cem Anos. Lisboa: Imprensa Nacional Casa da Moeda, 2000.

SALAS, Javier de - "Dos cartas sobre la expedición a Ceuta en 1415". O Instituto: o jornal scientifico e litterario 81 (1931), pp. 317-338.

SÃO LUIS, Francisco de - "Memória em que se apontam algumas noticias para a historia de el-rei D. João I e se refutam outras, que nela andam introduzidas". in Obras Completas do Cardeal Saraiva (D. Francisco de S. Luiz) Patriarcha de Lisboa. Vol. III. Ed. António Correia Caldeira. Lisboa: Imprensa Nacional, 1874, pp. 221-263. 
SERRANO, Luciano - Los conversos D. Pablo de Santa María y Alonso de Cartagena. Obispos de Burgos, gobernantes, diplomáticos y escritores. Madrid: Consejo Superior de Investigaciones Científicas, 1942. SERRANO DE HARO, Antonio - El embajador Don Pero López de Ayala (1332-1407). Madrid: Ministerio de Asuntos Exteriores de España, 2001.

SUÁREZ FERNÁNDEZ, Luis - Castilla, el cisma y la crisis conciliar (1378-1440). Madrid: Consejo Superior de Investigaciones Científicas, 1960.

SUÁREZ FERNÁNDEZ, Luis - Relaciones entre Portugal y Castilla en la época del infante don Enrique 1393-1460. Madrid: Consejo Superior de Investigaciones Científicas, 1960.

UNALI, Anna - Ceuta 1415. Los orígenes de la expansión europea en África. Ceuta: Archivo Central, 2004.

VENTURA, Margarida Garcez - O Messias de Lisboa. Um estudo de Mitologia Política (1383-1415). Lisboa: Cosmos, 1992.

\section{NOTAS}

1. Este estudio ha sido posible gracias al disfrute de una beca postdoctoral (bolsa de pósdoutoramento) financiada por la Fundação para a Ciência e a Tecnologia do Ministério da Educação e Ciência de Portugal (SFRH/BPD/94257/2013), encuadrado en el proyecto estratégico del CIDEHUS (UID/HIS/00057/2013).

2. CONTRERAS Y LÓPEZ DE AYALA, Juan de - "El cronista don Pedro López de Ayala y la historiografía portuguesa”. Boletín de la Real Academia de la Historia 102 (1933), pp. 115-157.

3. PERES, Damião - D. João I. Lisboa: Livraria Ferin, 1917, p. 18.

4. LOPES, Fernão - Crónica de D. João I. Vol. 1. Lisboa: Civilização editora, 1983, prólogo, p. 2.

5. SILVA, Joseph Soares da - Memorias para a Historia de Portugal que comprehendem o governo del rey

D. João I do anno de mil e trezentos e oitenta e tres, até o anno de mil e quatrocentos e trinta e tres. Lisboa: Academia Real, 1732.

6. SÃO LUIS, Francisco de - "Memória em que se apontam algumas noticias para a historia de elrei D. João I e se refutam outras, que nela andam introduzidas". in Obras completas do Cardeal Saraiva (D. Francisco de S. Luiz) Patriarcha de Lisboa. Vol. III. Ed. António Correia Caldeira. Lisboa: Imprensa Nacional, 1874, p. 231.

7. PERES, Damião - D. João I.

8. COELHO, Maria Helena da Cruz - D. João I, o que re-colheu Boa Memória. Lisboa: Círculo de Leitores, 2005.

9. VENTURA, Margarida Garcez - O messias de Lisboa. Um estudo de Mitologia Política (1383-1415). Lisboa: Cosmos, 1992.

10. FORONDA, François; GENET, Jean-Philippe; NIETO SORIA, José Manuel - Coups d'état à la fin du Moyen Âge? Aux foundaments du pouvoir politique en Europe Occidentale. Madrid: Casa de Velázquez, 2005.

11. OLIVERA SERRANO, César - Beatriz de Portugal. La pugna dinástica Avís-Trastámara. Santiago de Compostela: Consejo Superior de Investigaciones Científicas, Xunta de Galicia, Instituto de Estudios Gallegos Padre Sarmiento, 2005, p. 105.

12. Así aparece por ejemplo en el privilegio concedido el 16 de diciembre de 1387 a la ciudad de León para limitar la contribución de sus vecinos a la corona. Archivo General de Simancas (En adelante citado como AGS), Libros De Privilegios y Confirmaciones, libro 299, 12r. Editado como documento 136 en COLECCIÓN DE privilegios, franquezas, exenciones y fueros, concedidos a varios 
pueblos y corporaciones de la corona de Castilla copiados por orden de S. M. de los registros del Real Archivo de Simancas. Vol. V. Ed. Archivo General de Simancas. Madrid: Imprenta Real, 1830, pp. 416-419. 13. ORIOL PERNAS, António - "Acuñaciones de Juan I de Castilla como rey de Portugal”. Nummus, Série I, 33 (1974), pp. 65-74.

14. FERNÁNDEZ DE CÓRDOBA MIRALLES, Álvaro - "Los emblemas de la conquista: armas y divisas de Juan I Trastámara ante la sucesión portuguesa". Armas e trofeus, revista de história, heráldica, genealogia e arte 9 (2013), pp. 229-268.

15. NUNES DE LEÃO, Duarte - "Crónica del rey D. João I deste nome, e dos reys de Portugal o decimo". in Cronicas del rey dom João de gloriosa memoria, o I deste nome, e as dos reys D. Duarte e D. Afonso V. Tomo I. Ed. Rodrigo da Cunha. Lisboa: Oficina de Jose de Aquino Bulhoens, 1780, cap. XVII, pp. 63-70.

16. Biblioteca Capitular y Colombina de Sevilla, manuscrito BB 149-3, 1v. Editado parcialmente en LÓPEZ-MAYAN, Mercedes - "Los pontificales en Castilla durante la Edad Media: aproximación a una fuente de conocimiento histórico". in MIRANDA, Flavio; SEQUEIRA, Joana; FARIA, Diogo (eds.) - Incipit 2. Workshop de Estudos Medievais da Universidade do Porto. Porto: Universidade do Porto, 2014, p. 152.

17. Esta denominación aparece en un documento por el que Carlos VI de Francia otorgaba financiación a sus representantes en las negociaciones entre Juan I de Castilla y Juan de Gante en 1387. Archives Nationales de la France (En adelante citado como ANF), Série J, 603, número 63. Editado como documento 35 en DAUMET, Georges - Étude sur l'alliance de la France et de la Castille au XIVe et XV siècles. París: Libraire Émile Bouillon, 1898, pp. 175-176.

18. Archivo Secreto Vaticano (En adelante citado como ASV), Registra Vaticana, 297, 9r. Editado como documento 15 en SUÁREZ FERNÁNDEZ, Luis - Castilla, el cisma y la crisis conciliar (1378-1440). Madrid: Consejo Superior de Investigaciones Científicas, 1960, p. 165.

19. ASV, Registra Vaticana, 297, 75v. Editado como documento 17 en SUÁREZ FERNÁNDEZ, Luis Castilla, el cisma y la crisis conciliar, pp. 166-167.

20. ASV, Registra Vaticana, 310, 343v.-344v. Editado como documento 2 en BRÁSIO, António "Influência do cisma castelhano na solução da crise nacional de 1385". Lusitania Sacra 4 (1959), pp. 115-116.

21. AGS, Patronato Real, Legajo 52, documento 4. Editado en ECHEVARRIA, Ana - "Catalina of Lancaster, the Castilian Monarchy and the coexistance". in COLLINS, Roger; GOODMAN, Anthony (eds.) - Medieval Spain, culture, conflict and coexistance. Studies in Honour of Angus MacKay. New York: Palgrave Macmillan, 2002, pp. 104-105.

22. RUSSELL, Peter Edward - A intervenção inglesa na Península Ibérica durante a Guerra dos Cem Anos. Lisboa: Imprensa Nacional Casa da Moeda, 2000, pp. 563-585.

23. De este modo aparece en varias súplicas realizadas por la reina a la curia pontificia de Benedicto XIII. ASV, Registra Supplicationum, 90, 55v.-60v.; 99, 50v.; 100, 71r.-73r.; 73v.-79r.; 102, 240r.; 102, 142r.; 103, 50r.-50v.; 104, 221v.; 104, 262r. Editadas en COSTA, António Domingues da Sousa - Monumenta Portugaliae Vaticana (Vol. II: Súplicas dos pontificados dos papas de Avinhão Clemente VII e Bento XIII e do papa de Roma Bonifácio IX), Lisboa: Editorial Franciscana, 1970, pp. 298-309, 313, 317-318, 324-325, 339, 341, 346-347, 360, 365. Igualmente en una súplica realizada a la curia pontificia de Martin V. ASV, Registra Supplicationum, 116, 31v.-32r. Editada en COSTA, António Domingues da Sousa - Monumenta Portugaliae Vaticana (Vol. III/2: Súplicas do pontificado de Martinho V: anos 1-7), pp. 101-102.

24. ORIOL PERNAS, António - “Acuñaciones de Juan I de Castilla como rey de Portugal”, pp. 65-74.

25. FERNÁNDEZ DE CÓRDOBA MIRALLES, Álvaro - “Los emblemas de la conquista...”, pp. 229-268

26. OLIVERA SERRANO, César - Beatriz de Portugal, p. 358.

27. OLIVERA SERRANO, César - Beatriz de Portugal, pp. 116-117.

28. Como por ejemplo la carta enviada por Enrique III de Castilla a la ciudad de Burgos ordenándola hacer una leva para entrar en la guerra con Portugal en 1397. AGS, Diversos de 
Castilla, legajo 11, documento 7. Editada como documento 15 en SUÁREZ FERNÁNDEZ, Luis Relaciones entre Portugal y Castilla en la época del infante don Enrique 1393-1460. Madrid: Consejo Superior de Investigaciones Científicas, 1960, pp. 110-112.

29. De ese modo se refiere al monarca portugués en la solicitud que Enrique III de Castilla realiza a Carlos VI de Francia para que declarase la guerra a Portugal en 1397. ANF, Série J, 916, 4r. Editada como documento 33 en SUÁREZ FERNÁNDEZ, Luis - Relaciones entre Portugal y Castilla, pp. 98-99.

30. Por ejemplo aparece en la ratificación de Enrique III de Castilla de la tregua de 1402. AGS, Patronato Real, legajo 49, documento 4. Editada como documento 33 en SUÁREZ FERNÁNDEZ, Luis - Relaciones entre Portugal y Castilla, pp. 159-162.

31. AGS, Patronato Real, legajo 49, documento 3. Editado como documento 32 en SUÁREZ FERNÁNDEZ, Luis - Relaciones entre Portugal y Castilla, pp. 136-158.

32. Archives Nationales, Série K, 1482, 13r. Editada como documento 50 en DAUMET, Georges Étude sur l'alliance, pp. 204-206.

33. Archivo de la Corona de Aragón (En adelante citado como ACA), Registros reales, registro 2216, 11v.

34. Archives Nationales, Série K, 1482, 12r. Editada como documento 49 en DAUMET, Georges Étude sur l'alliance, pp. 206-207.

35. JARRY, Eugène - La vie politique de Louis de France, duc d'Orléans, 1372-1407. Paris: Alph. Picard, 1889 , p. 244.

36. AGS, Estado, Castilla, legajo 1-2º 2 r. Editada como documento 35 en SUÁREZ FERNÁNDEZ, Luis - Relaciones entre Portugal y Castilla, pp. 164-165.

37. Arquivo Nacional da Torre do Tombo (En adelante citado como ANTT), manuscrito 364, 457r. Editado en PIMENTA, Alfredo - "As trégoas de Monção de 1389". in Idade-Média (Problemas \& soluçoens), Lisboa: Edições Ultramar, 1946, pp. 317-328.

38. OLIVERA SERRANO, César - Beatriz de Portugal, p. 152

39. ÁLVAREZ PALENZUELA, Vicente Ángel - "El restablecimiento de la paz entre Castilla y Portugal 1402-1431". in HOMEM, Armando Luís de Carvalho; PIZARRO, José Augusto de Sotto Mayor; COSTA, Paula María de Carvalho Pinto (coords.) - Ibéria, quatrocentos/quinhentos, duas décadas de cátedra (1984-2006): homenagem a Luís Adão da Fonseca. Porto: Civilização Editora, p. 89. OLIVERA SERRANO, César - Beatriz de Portugal, pp. 189-192.

40. ANTT, Gaveta 18, maço 11, documento 4. Editado como documento 5 en MONUMENTA HENRICINA. Vol. II. Ed. Manuel Lopes de Almeida. Coimbra: Comissão executiva das comemorações do V centenário da morte do infante D. Henrique, 1962, pp. 7-25, y en AS GAVETAS da Torre do Tombo. Vol. IX. Ed. António da Silva Rego. Lisboa: Centro de Estudos Históricos Ultramarinos, 1971, pp. 608-636.

41. Archives Nationales de la France, Série J, 604, número 77. Editado como documento 55 en DAUMET, Georges - Étude sur l'alliance, pp. 220-222.

42. SERRANO DE HARO, Antonio - El embajador Don Pero López de Ayala (1332-1407). Madrid: Ministerio de Asuntos Exteriores de España, 2001, pp. 98-111.

43. LÓPEZ DE AYALA, Pedro - "Crónica de Don Enrique III de Castilla". in Crónicas de los reyes de Castilla Don Pedro, Don Enrique II, Don Juan I y Don Enrique III por D. Pedro López de Ayala, chanciller mayor de Castilla, con las enmiendas del secretario Gerónimo Zurita. Vol. 2. Ed. Eugenio Llaguna Amirola. Madrid: Imprenta de Don Antonio de Sancha, 1780, cap. I, pp. 459-462.

44. LÓPEZ DE AYALA, Pedro - "Crónica de Don Enrique III de Castilla", cap. XIII, pp. 450-452.

45. LÓPEZ DE AYALA, Pedro - “Crónica de Don Juan I de Castilla". in Crónicas de los reyes de Castilla Don Pedro, Don Enrique II, Don Juan I y Don Enrique III por D. Pedro López de Ayala, chanciller mayor de Castilla, con las enmiendas del secretario Gerónimo Zurita. Vol. 2. Ed. Eugenio Llaguna Amirola. Madrid: Imprenta de Don Antonio de Sancha, 1780, cap. VI, pp. 213-214.

46. LOPES, Fernão - Crónica de D. João I. Vol. 2, cap. XII, pp. 28-30. 
47. LÓPEZ DE AYALA, Pedro - “Crónica de Don Juan I de Castilla", cap. VII, pp. 250-252.

48. BRÁSIO, António - “As razões de João das Regras nas cortes de Coimbra”. Lusitania Sacra 3 (1958), pp. 14-15.

49. BRÁSIO, António - "Influência do Cisma...", pp. 103-110. CAETANO, Marcelo - A crise nacional de 1383-1385. Subsídios para o seu estudo. Lisboa-São Paulo: Verbo, pp. 44-49. COELHO, Maria Helena da Cruz - D. João I, p. 67.

50. ANTT, Bulas, maço 5, documento 9; ASV, Registra Lateranensia, 12, 10v.-12v.; y ANTT, Leitura Nova, livro 38 (Livro I dos Reis), fols. 8r.-9v. Publicada en COSTA, Antonio Domingues de Sousa Monumenta Portugaliae Vaticana, vol. 2, pp. CVIII-CXXII.

51. LOPES, Fernão - Crónica de D. João I, vol. 2, caps. CXXIV-CXXV, pp. 274-281.

52. VALDALISO CASANOVA, Covadonga - "La obra cronística de Pedro López de Ayala y la sucesión monárquica en la Corona de Castilla”. Edad Media, revista de historia 12 (2011), p. 198.

53. LÓPEZ DE AYALA, Pedro - “Crónica de Don Juan I de Castilla”, cap. VII, pp. 175-176.

54. LOPES, Fernão - Crónica de D. Fernando. Ed. Giuliano Macchi. Lisboa: Imprensa Nacional Casa da Moeda, 2004, caps. CLXXII-CLXXVIII, pp. 591-612.

55. La enemistad entre Leonor Teles y su cuñado D. João I de Portugal es una constante en la narración de Fernão Lopes, COELHO, Maria Helena da Cruz - D. João I, p. 18.

56. LÓPEZ DE AYALA, Pedro - "Crónica de Don Juan I de Castilla", cap. XII, pp. 225-227.

57. LOPES, Fernão - Crónica de D. Fernando, cap. CLXVII, pp. 575-577.

58. OLIVERA SERRANO, César - Beatriz de Portugal, p. 358.

59. LÓPEZ DE AYALA, Pedro - “Crónica de Don Juan I de Castilla”, cap. VI, pp. 269-270.

60. RUSSELL, Peter Edward - A intervenção inglesa, pp. 435-586.

61. LOPES, Fernão - Crónica de D. João I, vol. 2, cap. LXXXVIII, p. 216-217.

62. LOPES, Fernão - Crónica de D. João I, vol. 2, caps. XC-XCII, pp. 222-225.

63. LOPES, Fernão - Crónica de D. João I, vol. 2, cap. CXXI, p. 268.

64. LÓPEZ DE AYALA, Pedro - "Crónica de Don Juan I de Castilla", cap. XIV, pp. 183-184.

65. LÓPEZ DE AYALA, Pedro - “Crónica de Don Juan I de Castilla”, cap. VI, pp. 213-214.

66. LOPES, Fernão - Crónica de D. João I, vol. 1, cap. I, p. 4.

67. LÓPEZ DE AYALA, Pedro - “Crónica de Don Juan I de Castilla”, cap. XIV, pp. 183-184.

68. BEIRANTE, Maria Ângela - As estruturas sociais em Fernão Lopes. Lisboa: Livros Horizonte, 1984.

69. LÓPEZ DE AYALA, Pedro - “Crónica de Don Juan I de Castilla”, cap. X, pp. 197-198.

70. FARELO, Mário - "O percurso eclesiástico e político de Afonso Domingues de Linhares, bispo de Guarda (1364-1394) e de Segóvia (1394-1397)”. Estudios segovianos 60-112 (2013), pp. 277-323.

71. LÓPEZ DE AYALA, Pedro - “Crónica de Don Juan I de Castilla”, cap. X, pp. 179-180.

72. LOPES, Fernão - Crónica de D. João I, vol. 1, cap. LVII, pp. 113-114.

73. LÓPEZ DE AYALA, Pedro - "Crónica de Don Juan I de Castilla", cap. VII, pp. 214-217.

74. LOPES, Fernão - Crónica de D. João I, vol. 2, caps. IX-XII, pp. 22-30.

75. SUÁREZ FERNÁNDEZ, Luis - Relaciones entre Portugal y Castilla, p. 36.

76. AGS, Estado, Castilla, legajo 1-1º, 73r. Editado como documento 21 en SUÁREZ FERNÁNDEZ, Luis - Relaciones entre Portugal y Castilla, p. 122.

77. Gabinete de História da Câmara do Porto, Vereações, libro 2, 47v. Editado como documento 119 en MONUMENTA HENRICINA, vol. I, p. 277.

78. GONZÁLEZ SÁNCHEZ, Santiago - Fernando I, regente de Castilla y rey de Aragón. Gijón: TREA, 2012, p. 181.

79. ZURITA, Jerónimo - Anales de la corona de Aragón. Vol. 5. Ed. Ángel Canellas López. Zaragoza: Institución Fernando el Católico, 1974, libro XII, cap. LII, pp. 441-443.

80. ACA, Cartas reales, caja 1, Fernando I, n 3. Editado como doc. 1 en SALAS, Javier de - "Dos cartas sobre la expedición a Ceuta en 1415”. O Instituto: o jornal scientifico e litterario 81 (1931), pp. 320-337, y como doc. 57 en MONUMENTA HENRICINA, vol. II, pp.132-146. 
81. ACA, Cartas reales, caja 1, Fernando I, número 3. Editado como doc. 1 en SALAS, Javier de “Dos cartas...", pp. 320-337, y como doc. 57 en MONUMENTA HENRICINA, vol. II, pp. 132-146.

82. UNALI, Anna - Ceuta 1415. Los orígenes de la expansión europea en África. Ceuta: Archivo Central, 2004, pp. 207-223.

83. ACA, Registros reales, registro $2405,56 \mathrm{v}$., $142 \mathrm{v}$; registro $2408,17 \mathrm{r}$. Editada como documento 107 en MONUMENTA HENRICINA, vol. II, pp. 225-226.

84. ACA, Cartas reales, caja 13, Fernando I, número 2490. Editada como documento 49 en MONUMENTA HENRICINA, vol. II, pp. 121-122.

85. ACA, Cartas reales, caja 18, Alfonso V, número 1. Editada como documento 49 en MONUMENTA HENRICINA, vol. II, pp. 121-122.

86. SUÁREZ FERNÁNDEZ, Luis - Relaciones entre Portugal y Castilla, p. 35.

87. DUNPHY, Graeme (ed.) - Encyclopedia of the Medieval Chronicle. Vol I. Leiden: Brill, 2010, p. 661.

88. SERRANO, Luciano - Los conversos D. Pablo de Santa María y Alonso de Cartagena. Obispos de Burgos, gobernantes, diplomáticos y escritores. Madrid: Consejo Superior de Investigaciones Científicas, 1942, pp. 61-62.

89. GÓMEZ REDONDO, Fernando - "Discurso y elocución en la Crónica de Juan II (1406-1434)". Cahiers de linguistique et de civilisation hispaniques médiévales 27 (2004), pp. 231-234

90. MATA CARRIAZO, Juan de - "La conquista de Ceuta en la crónica de Juan II de Álvar García de Santa María”. Anais da Academia Portuguesa da História, II Série, 27 (1982), pp. 281-295.

91. MORENO, Humberto Baquero - "O valor da Crónica de Zurara sobre a conquista de Ceuta". in A abertura do mundo, estudos da história dos descobrimentos europeus. Em homenagem a Luís de Alburquerque. Vol. II. Lisboa: Presença, 1987, pp. 191-202.

92. MATA CARRIAZO, Juan de - “La conquista de Ceuta...", p. 287.

93. DUNPHY, Graeme (ed.) - Encyclopedia of the Medieval Chronicle, vol. 2, p. 1200

94. DUNPHY, Graeme (ed.) - Encyclopedia of the Medieval Chronicle, vol. 1, p. 251.

95. DUNPHY, Graeme (ed.) - Encyclopedia of the Medieval Chronicle, vol. 1, p. 251.

96. BARRIENTOS, Lope de - Refundición de la Crónica del Halconero. Ed. Juan de Mata Carriazo. Madrid: Espasa Calpe, 1946, cap. I, pp. 11-12.

97. FONSECA, Luis Adão da - "Alguns aspectos das relações diplomáticas entre Portugal e Castela em meados do século XV (1449-1456)". Revista da Faculdade de Letras: História, I série, 3 (1972) pp. 51-112. FONSECA, Luis Adão da - "Una elegía inédita sobre la familia de Avis, un aspecto de la propaganda política en la Península Ibérica a mediados del siglo XV". Anuario de Estudios Medievales 16 (1986), p. 449.

98. DUARTE, Luis Miguel - Ceuta 1415, seiscentos anos depois. Lisboa: Horizonte, 2015, pp. 35-36.

99. FONSECA, Luis Adão da - "Una elegía inédita...", p. 459.

100. CÓRDOBA, Alonso de - Conmemoración breve de los reyes de Portugal. Un sermón castellano. Ed. Pedro Cátedra. Barcelona: Humanitas, 1983, p. 44.

101. DUNPHY, Graeme (ed.) - Encyclopedia of the Medieval Chronicle, vol. 2, pp. 1466-1467.

102. DUNPHY, Graeme (ed.) - Encyclopedia of the Medieval Chronicle, vol. 2, p. 1183.

103. VALERA, Diego de - Memorial de Diversas Hazañas. Crónica de Enrique IV. Ed. Juan de Mata Carriazo. Madrid: Espasa Calpe, 1941, cap. XXII, pp. 87-89.

104. PALENCIA, Alonso de - Gesta Hispaniensa ex annalibvs svorvm diervm collecta (Tomo 1 - Libri I-V). Ed. Brian Tate y Jeremy Lawrence. Madrid: Real Academia de la Historia, 1998, lib. I, cap. 10, pp. 30-31.

105. ÁLVAREZ PALENZUELA, Vicente Ángel - "Relations between Portugal and Castile in the Late Middle Ages - 13th-16th centuries". E-Journal of Portuguese History 1 (2003), p. 15.

106. DUNPHY, Graeme (ed.) - Encyclopedia of the Medieval Chronicle, vol. 1, p. 781.

107. PULGAR, Fernando del - Crónica de los Reyes Católicos (Volumen I: la guerra de Granada). Ed. Juan de Mata Carriazo. Granada: Universidad de Granada, 2008, p. 175. 


\section{RESÚMENES}

A proclamação de D. João I de Portugal e o estabelecimento de uma nova dinastia levou à criação de vários discursos propagandísticos. A historiografía portuguesa deu-lhe particular destaque em detrimento dos seus descendentes, tendo sido consagrado pela crónica de Fernão Lopes. Em contrapartida, este texto pouco referiu a trama construída contra D. João pelos Transtâmara que reividicavam o trono português sob os direitos de Beatriz de Portugal. Através da análise do discurso das crónicas de Pedro López de Ayala, das epístolas de Fernando de Castela, da documentação da chancelaria castelhana e de outros instrumentos de poder, como o selo e a moeda, podemos não só observar as reivindicações dos Trastâmara e o seu não-reconhecimento da dinastia de Avis, mas também a construção da imagem de um D. João I de Portugal como governante indigno. Tanto pelas suas condições pessoais (bastardia e clérigo), como pelo seu modo de governação traiçoeiro, cobarde, vacilante e oportunista. Trata-se de uma imagem radicalmente distinta das fontes portuguesas, que o estabelecem como o monarca de "boa memória" e o "messias de Lisboa"; uma alternativa, pois, que surge no discurso político da época.

The constitution of a new dynasty with the proclamation of D. João I of Portugal led to the creation of various propagandistic discourses. Portuguese historiography has only focused on the one created in his favor by his descendants, consecrated in the chronicle of Fernão Lopes. On the other hand, it has scarcely taken care of the constructed against it by the Castilian Trastámara who claimed the Portuguese throne under the rights of Beatriz of Portugal. Through the analysis of the discourse of the chronicles of Pedro López Ayala, the epistles of Fernando de Castilla, the documentation of the Castilian Chancellery and other instruments of power, such as the seal and the currency, we can not only observe the claims of the Trastámara and their non-recognition of the Avis dynasty, but also the construction of the image of D. João I of Portugal as an unworthy ruler by his personal conditions (barstardy and clergyman) and his style of governing in a traitorous, cowardly, hesitant, and opportunistic way. An image of the Portuguese sovereign radically different from that of the "good memory" and the "messiah of Lisbon" consecrated by the Portuguese sources, an alternative that appeared in the political discourse of the time.

\section{ÍNDICE}

Keywords: Dynastic legitimacy, Dynastic delegitimization discourses, Crisis of 1383-1385 in Portugal, Portuguese-Castilian relations, Late-medieval political history

Palavras-chave: Legitimidade dinástica, discursos de não legitimação dinástica, Crise de 1383-1385 em Portugal, relações luso-castelhanas, história política da Baixa Idade Média

\section{AUTOR}

\section{NÉSTOR VIGIL MONTES}

Universidade de Évora, CIDEHUS - Centro Interdisciplinar de História, Culturas e Sociedades, 7000-809, Évora, Portugal 
vigilnestor@gmail.com 